\title{
リチウムイオン電池における界面電荷移動反応
}

\author{
安部 武志・小久見 善八 \\ 京都大学大学院工学研究科 函 615-8510 京都府京都市西京区京都大学桂
}

(2006 年 6 月 9 日受理)

\section{Charge Transfer Reactions in Lithium-ion Batteries}

\author{
Takeshi ABE and Zempachi OGUMI \\ Graduate School of Engineering, Kyoto University \\ Kyodaikatsura, Nishikyo-ku, Kyoto 615-8510
}

(Received June 9, 2006)

\begin{abstract}
We have studied the charge transfer reactions at electrode/electrolyte interfaces in lithium-ion batteries and found that there exist large activation barriers at the interface for lithium-ion to insert and extract at the electrodes. By the theoretical calculation, the activation barriers were found to be correlated with the interaction between lithium-ion and solvent in electrolyte, and therefore, the activation barriers are principally due to the de-solvation process of lithium-ion in the electrolyte. These results are also confirmed by the model interface consisted of electrolyte/electrolyte. Based on these results, we discuss how the rate performance of lithium-ion batteries will be enhanced.
\end{abstract}

\section{1.は じめに}

リチウムイオン電池は 1991 年に市販されて以来，小 型携帯用機器電源として普及し, とくに携帯電話の進歩 とともに, 電池も年々進歩している。また, 更なる高容 量化を目指して, 現在の電池を構成しているリチウム含 有遷移金属酸化物正極, 黒鉛化炭素材料負極に代わる活 物質の探索など, 未だに研究開発にしのぎが削られてい る。最近ではリチウムイオン電池はニッケル水素電池に 代わるハイブリッド自動車 (HEV) 用電源としても注 目を集めている。リチウムイオン電池を HEV 用途に使 用する場合, 安全性の向上ならびに出入力特性の向上を はかることが重要となる。出入力特性を向上させるため には電池の内部抵抗を低減させることが必要である。 我々はリチウムイオン電池の出入力特性を向上させるた めに, 内部抵抗の主要因となるリチウムイオン輸送に着 目し, 特にリチウムイオン電池の電極/電解質界面での 電荷 (リチウムイオン) 移動反応を調べてきた。その結 果, 界面でのイオン移動には大きな活性化障壁が存在す ることを明らかにした。活性化障壁の要因を調べるため, 種々の電解質を用いて界面でのイオン移動に伴う活性化

E-mail: abe@elech.kuic.kyoto-u.ac.jp
エネルギーを得た。これらの結果と理論計算により, リ チウムイオンと溶媒の相互作用が活性化エネルギーの主 たる要因であることを明らかにした。ここでは, 界面イ オン移動について得られた最近の我々の結果を中心に述 ベる。

\section{2. 黒鉛電極への溶媒和リチウムイオン移動 反応 ${ }^{1)}$}

リチウムイオン電池の電極/電解質界面でホスト材料 への挿入時の脱溶媒和反応が律速段階になる可能性を示 唆した結果として, 黒鉛電極への溶媒和リチウムイオン 移動反応を紹介する。高配向性熱分解黒鉛（HOPG）を 作用極とし, 電解液に $1 \mathrm{~mol} \mathrm{dm}{ }^{-3} \mathrm{LiCF}_{3} \mathrm{SO}_{3} / \mathrm{DME}$ (ジメ トキシエタン) もしくはDMSO（ジメチルスルフォキシ ド）を用いるとDME（あるいは DMSO）に溶媒和され たリチウムイオンが可逆的に黒鉛に挿入脱離する。そこ でこの反応を交流インピーダンス法により調べた結果を Fig. 1 に示す。浸漬電位では溶媒和リチウムイオンの挿 入脱離反応が生じないためにブロッキング電極の挙動を 示したが，黒鉛に溶媒和リチウムイオンが挿入脱離する 電位より低い電位から円弧成分が認められた。この円弧 の大きさが電位依存性を示し, また電解質塩濃度にも依 存することにより, この円弧は電荷（溶媒和リチウムイ 
オン）移動抵抗と帰属できる。この電荷移動抵抗の温度 依存性より溶媒和リチウムイオンの挿入脱離反応に対す る活性化エネルギーを求めた結果, 約 $25 \mathrm{~kJ} \mathrm{~mol}^{-1}$ の值 を得た。一方, 同じ HOPG を電極とし, リチウムイオ ンを電気化学的に挿入脱離させ, 交流インピーダンス測 定を行った。その結果を Fig. 2 に示す。黒鉛負極の電位 を $1 \mathrm{~mol} \mathrm{dm}^{-3} \mathrm{LiClO}_{4} / \mathrm{EC}+\mathrm{DEC}(1: 1)$ の電解液中で約 $3 \mathrm{~V}(\mathrm{OCV})$ から $0.2 \mathrm{~V}\left(\mathrm{Li} / \mathrm{Li}^{+}\right)$まで変化させたとき（測 定前にサイクリックボルタンメトリーを 0〜 3.0 V の範 囲で行い，黒鉛負極表面には表面被膜を形成させてい る)，電位 $0.8 \mathrm{~V}$ まではブロッキング電極を用いたとき の挙動に類似したキャパシタンス成分しか認められない が, 黒鉛電極にリチウムイオンが挿入し始める電位約 0.6 $\mathrm{V}$ になると, 低周波数側に円弧が認められた。さきほど と同様, この円弧成分は電解液中の塩濃度にも比例して, 円弧の大きさが変化することから，この円弧は電荷（リ チウムイオン）移動反応によるものであることが明確と なった。この円弧の特性周波数は $50 \mathrm{mHz}$ と非常に小さ い值であることがわかる。リチウムイオン移動抵抗の温 度依存性より活性化エネルギーは 53〜 $59 \mathrm{kJmol}^{-1}$ の值

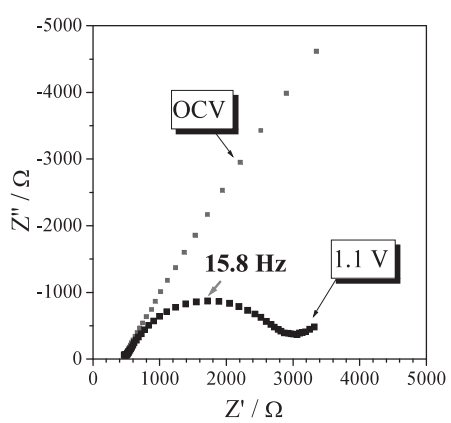

Fig. 1. Nyquist plot of graphite (HOPG) in $1 \mathrm{~mol} \mathrm{dm}^{-3}$ $\mathrm{LiCF}_{3} \mathrm{SO}_{3} / \mathrm{DME}$.

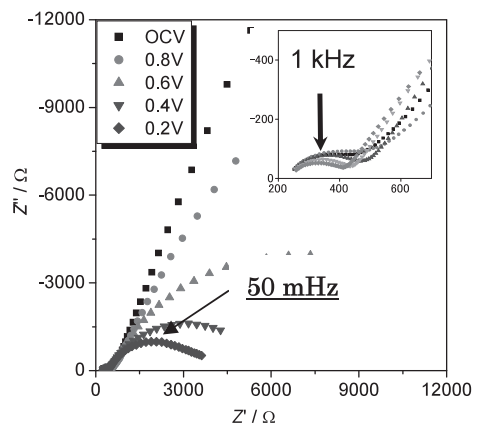

Fig. 2. Nyquist plots of graphite (HOPG) electrode in $1 \mathrm{~mol}$ $\mathrm{dm}^{-3} \mathrm{LiClO}_{4} / \mathrm{EC}+\mathrm{DEC}(1: 1)$ at various potentials $\left(\mathrm{Li} / \mathrm{Li}^{+}\right)$.
となり，溶媒和リチウムイオンの挿入脱離反応に伴う活 性化エネルギーの 2 倍以上の值となった。これらの結果 より，黒鉛/電解質界面でのリチウムイオン移動反応は 遅く, その主要因は脱溶媒和反応であることを見出した。

また，黒鉛電極に $\mathrm{CF}_{3} \mathrm{SO}_{3}$-アニオンを電気化学的に 挿入脱離させた場合では，約 $30 \mathrm{~kJ} \mathrm{~mol}^{-1}$ 程度の活性化 障壁を得た。電解液中のアニオンは溶媒との相互作用が カチオンよりも小さく，低い活性化エネルギーを示した ことが考えられ，上述の結果と良い一致を示している。

\section{3. 正極/電解質界面 ${ }^{2 \sim 4)}$}

次に正極と電解質界面での電荷移動反応について述べ る。負極ではモデル活物質としてブロック上の HOPG を用いることができたが，正極ではそのような材料はな い。そこで，バインダーフリーな薄膜電極を作製し，電 極/電解質界面でのイオン移動の議論を容易にした。市 販のリチウムイオン電池で用いられている典型的な正極 材料である $\mathrm{LiCoO}_{2}$ および $\mathrm{LiMn}_{2} \mathrm{O}_{4}$ 薄膜電極をレーザー アブレーション法により作製した。3 極式セルを構築し, 交流インピーダンス測定を行った結果を Fig. 3 に示す。 電解液には炭酸プロピレン (PC) に $1 \mathrm{~mol} \mathrm{dm}^{-3} \mathrm{LiCF}_{3} \mathrm{SO}_{3}$ を溶解させたものを使用した。 $3.80 \mathrm{~V}$ 以下では $\mathrm{LiCoO}_{2}$ からリチウムイオンがほとんど抜けていないために，円 弧が認められずブロッキング電極に特徵的なスペクトル を得た。一方， $3.92 \mathrm{~V}\left(\mathrm{vs} . \mathrm{Li} / \mathrm{Li}^{+}\right)$以上の電位では円 弧が 1 つ認められた。本研究で用いた $\mathrm{LiCoO}_{2}$ の膜厚は $0.1 \sim 0.3 \mu \mathrm{m}$ と非常に薄いために電子抵抗は小さい。さ らに円弧の特性周波数は $1 \mathrm{~Hz}$ と非常に遅く, 薄膜面積 が小さいことを考慮すると電子移動によるものとは考え にくい。このことから円弧成分はリチウムイオンが関与 する緩和現象に対応する。この円弧成分の帰属をより明 確にするために，ここで生じるインピーダンスのリチウ ム塩濃度依存性を調べた。Fig. 4 に結果を示す。インピ

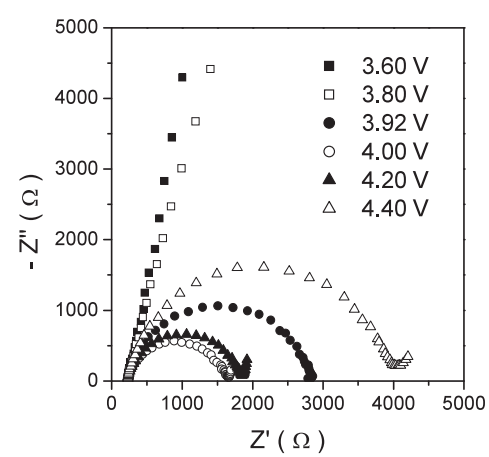

Fig. 3. Nyquist plots for liquid electrolyte/ $\mathrm{LiCoO}_{2}$ thin film interface. 


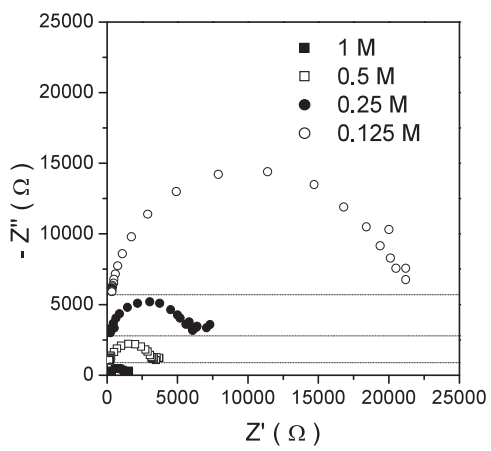

Fig. 4. Nyquist plots for liquid electrolyte/ $\mathrm{LiCoO}_{2}$ thin film interface with various concentrations of electrolyte.

ーダンスは濃度が半分になるにつれほぼ倍となった。す なわち, このインピーダンスは溶液中のリチウムイオン が関与する反応の緩和過程であり，この円弧は電荷（リ チウムイオン）移動抵抗であることを明確にした。

溶媒にプロピレンカーボネートより電子供与性の強い クラウンエーテルを添加した結果, より大きな活性化エ ネルギーを与えることがわかった。 $\mathrm{LiCoO}_{2} /$ 電解質界面 の電極反応は数多くの素過程を含んでいることが考えら れるが，これらの結果は，電極反応に影響を与える過程 の 1 つとして脱溶媒和過程が存在することを示し, 黒鉛 電極での結果と整合性を示した。

\section{4. 電解質/電解質界面 ${ }^{5,6}$}

（1）ポリマー電解質/セラミック電解質界面

より詳細に電荷移動反応を調べるために，2 種類の電 解質を用いて電子移動反応を生じないモデル界面を構築 し, その間のイオン移動反応について調べた。電解質に はポリエチレンオキシドから作製したポリマー電解質,

ペロブスカイト型酸化物であり, 高いリチウムイオン伝 導性を示す $\mathrm{La}_{0.55} \mathrm{Li}_{0.35} \mathrm{TiO}_{3}$, リチウムイオン伝導性ガラ 又電解質（OHARA 社製）などである。

モデルセル $\mathrm{Li} / \mathrm{PEO}-\mathrm{LiCF}_{3} \mathrm{SO}_{3} / \mathrm{La} 0.55 \mathrm{Li}_{0.35} \mathrm{TiO}_{3} / \mathrm{PEO}-$ $\mathrm{LiCF}_{3} \mathrm{SO}_{3} / \mathrm{Li}$ について交流インピーダンス測定を行った 結果を Fig. 5 に示した。高周波数側（特性周波数：約 10 $\mathrm{kHz}$ ）と低周波数側（特性周波数：約 $100 \mathrm{~Hz}$ ）に2つの 円弧が認められる。この系の抵抗を考えると，1）PEO-

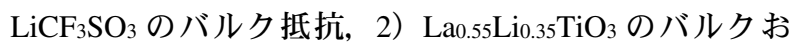

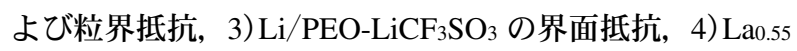

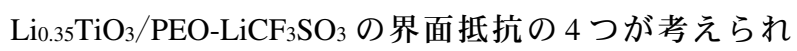
る。そこで, $\mathrm{Li} / \mathrm{PEO}-\mathrm{LiCF}_{3} \mathrm{SO}_{3} / \mathrm{Li}, \mathrm{SUS}$ (ステンレス鋼)/ $\mathrm{PEO}-\mathrm{LiCF}_{3} \mathrm{SO}_{3} / \mathrm{SUS}, \mathrm{Au} / \mathrm{La} 0.55 \mathrm{Li}_{0.35} \mathrm{TiO}_{3} / \mathrm{Au}$ の 3 種類 の

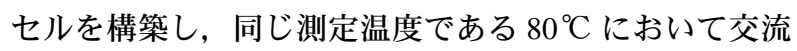
インピーダンス測定を行った。その結果, $\mathrm{PEO}_{-} \mathrm{LiCF}_{3} \mathrm{SO}_{3}$

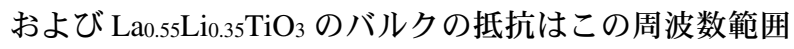

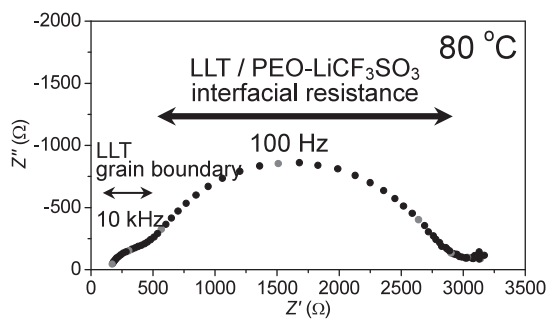

Fig. 5. Nyquist plot for interfaces of $\mathrm{Li} / \mathrm{PEO}-\mathrm{LiCF}_{3} \mathrm{SO}_{3} /$ $\mathrm{La}_{0.55} \mathrm{Li}_{0.35} \mathrm{TiO}_{3} / \mathrm{PEO}-\mathrm{LiCF}_{3} \mathrm{SO}_{3} / \mathrm{Li}$.

$t\left({ }^{\circ} \mathrm{C}\right)$
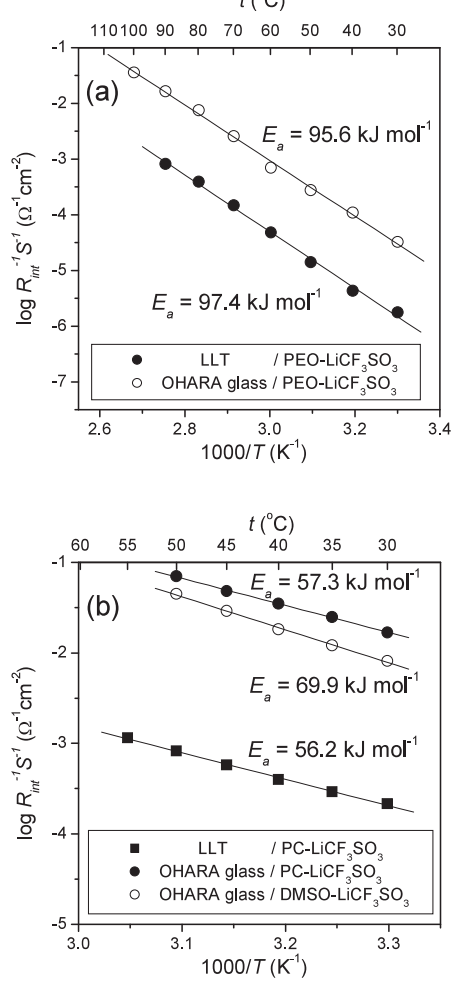

Fig. 6. Temperature dependence of interfacial resistance for (a) $\mathrm{La} 0.55 \mathrm{Li} 0.35 \mathrm{TiO}_{3} / \mathrm{PEO}-\mathrm{LiCF}_{3} \mathrm{SO}_{3}, \mathrm{OHARA}$ glass/ PEO-LiCF $\mathrm{SO}_{3}$, (b) La0.55Li0.35 $\mathrm{TiO}_{3} / \mathrm{PC}-\mathrm{LiCF}_{3} \mathrm{SO}_{3}$, OHARA glass $/ \mathrm{PC}_{-} \mathrm{LiCF}_{3} \mathrm{SO}_{3}$ and OHARA glass/ DMSO-LiCF $3 \mathrm{SO}_{3}$.

では円弧成分を与えず，高周波数側の円弧成分は La0.55 $\mathrm{Li}_{0.35} \mathrm{TiO}_{3}$ の粒界抵抗と $\mathrm{Li} / \mathrm{PEO}-\mathrm{LiCF}_{3} \mathrm{SO}_{3}$ の界面抵抗の 混在したものであることを明確にした。これらの結果よ り, Fig. 5 の低周波数成分は $\mathrm{La} 0.55 \mathrm{Li}_{0.35} \mathrm{TiO}_{3} / \mathrm{PEO}-\mathrm{LiCF}_{3}$ $\mathrm{SO}_{3}$ 界面でのイオン移動による抵抗であることがわかっ た。

$\mathrm{La} 0.55 \mathrm{Li}_{0.35} \mathrm{TiO}_{3} / \mathrm{PEO}-\mathrm{LiCF}_{3} \mathrm{SO}_{3}$ 界面抵抗の温度依存を 調べ活性化エネルギー $97.4 \mathrm{~kJ} \mathrm{~mol}^{-1}$ を得た。この值は このセルで用いた電解質中をリチウムイオンが伝導する ときの活性化エネルギーよりも大きい。すなわち, 電解 質/電解質界面でのイオン移動には高い活性化障壁が存 
在することがわかった。

（2）セラミック電解質/電解液界面

セラミック電解質として La0.55Li0.35 $\mathrm{TiO}_{3}$, OHARA 社 製ガラス電解質（OHARA glass）を用い, 四電極式のセ ルにより，界面イオン移動に伴う活性化エネルギーを調 ベた。電解液には $1 \mathrm{~mol} \mathrm{dm}^{-3} \mathrm{LiCF}_{3} \mathrm{SO}_{3} / \mathrm{PC}$ (or DMSO)を 用いた。 Li 金属/電解液界面の影響を除くために, 4 極 式交流インピーダンス測定を行った。測定は $30 \sim 55^{\circ} \mathrm{C}$ の温度範囲で行った。

$\mathrm{La} 0.55 \mathrm{Li}_{0.35} \mathrm{TiO}_{3} / \mathrm{PEO}-\mathrm{LiCF}_{3} \mathrm{SO}_{3}$, OHARA glass/PEO$\mathrm{LiCF}_{3} \mathrm{SO}_{3}, \quad \mathrm{La} 0.55 \mathrm{Li}_{0.35} \mathrm{TiO}_{3} / \mathrm{PC}-\mathrm{LiCF}_{3} \mathrm{SO}_{3}$, OHARA glass/ $\mathrm{PC}-\mathrm{LiCF}_{3} \mathrm{SO}_{3}$ 界面抵抗の温度依存性を Fig. 6 (a), (b)に 示した。界面イオン移動の活性化エネルギー $\left(E_{a}\right)$ はセ ラミック電解質（La0.55 $\mathrm{Li}_{0.35} \mathrm{TiO}_{3}$, OHARA glass）によら ずほぼ一定で, $\mathrm{PEO}-\mathrm{LiCF}_{3} \mathrm{SO}_{3}$ を用いた時に約 $96 \mathrm{~kJ}$

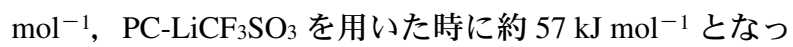
た。このことから界面イオン移動の活性化エネルギーは セラミック電解質の影響を受けず, 電解質の溶媒和の影 響を受けることがわかった。

OHARA glass/DMSO-LiCF $\mathrm{SO}_{3}$ の界面イオン移動の活 性化エネルギーは OHARA glass $/ \mathrm{PC}-\mathrm{LiCF}_{3} \mathrm{SO}_{3}$ のそれと 比較して, 約 $14 \mathrm{~kJ} \mathrm{~mol}^{-1}$ ほど大きいことがわかった。 密度汎関数法を用いて, リチウムイオンと PC もしくは DMSO との 1 対 1 の錯体を形成したときの生成エンタ ルピーを比較すると, DMSO-Li+イオン錯体のほうが, $\mathrm{PC}-\mathrm{Li}^{+}$イオン錯体より $18.4 \mathrm{~kJ} \mathrm{~mol}{ }^{-1}$ 大きいことがわか り，この值はほぼ活性化エネルギーの差と一致した。す なわち，イオン移動の活性化障壁はリチウムイオンと電 解質中の溶媒とのイオン一双極子相互作用に影響を受け
ていることが明らかとなった。

\section{5. おわりに}

リチウムイオン電池用負極/電解質, 正極/電解質, 電 解質/電解質間における電荷移動反応を交流インピーダ ンス法により調べた結果を記載した。これらの結果より, リチウムイオン電池内の電極/電解質間の電荷移動反応 は遅く, HEV 用途にリチウムイオン電池を用いるとき には電荷移動反応を促進させることが重要であることが 示唆された。また，界面での電荷移動に対する高い活性 化障壁は，電解液中のイオン一溶媒間の相互作用に起因 することを明確にし，すなわち，リチウムイオン電池の 高出入力化を図るためには，イオン一双極子相互作用を 低減させる，もしくは，界面でのリチウムイオンの遷移 状態を低減できるような界面の構築が必要であろう。

\section{文献}

1) T. Abe, H. Fukuda, Y. Iriyama and Z. Ogumi: J. Electrochem. Soc. 151, A 1120 (2004).

2) Z. Ogumi, T. Abe, T. Ohkubo, I. Yamada, Y. Iriyama, and N. Inaba: Proc. 200th Electrochemical Society, Rechargeable Lithium Batteries Symposium, Phoenix, Arizona, Fall 2000 (2000) p. 388.

3) Z. Ogumi, T. Abe and Y. Iriyama: Solid State Ionics: Trends in the new millenium, 3 (2002).

4) I. Yamada, T. Abe, Y. Iriyama and Z. Ogumi: Electrochem. Commun. 5, 502 (2003).

5) T. Abe, M. Ohtsuka, F. Sagane, Y. Iriyama and Z. Ogumi: J. Electrochem. Soc. 151, A 1950 (2004).

6) T. Abe, F. Sagane, M. Ohtsuka, Y. Iriyama and Z. Ogumi: J. Electrochem. Soc. 152, A 2151 (2005) 